\title{
American Studies, Cultural History, and the Critique of Culture
}

Richard S. Lowry

College of William and Mary, rslowr@wm.edu

Follow this and additional works at: https://scholarworks.wm.edu/aspubs

Part of the American Literature Commons, Cultural History Commons, Literature in English, North America Commons, and the United States History Commons

\section{Recommended Citation}

Lowry, Richard S., American Studies, Cultural History, and the Critique of Culture (2009). Journal of the Gilded Age and Progressive Era, 8(3), 301-339.

https://scholarworks.wm.edu/aspubs/372

This Article is brought to you for free and open access by the Arts and Sciences at W\&M ScholarWorks. It has been accepted for inclusion in Arts \& Sciences Articles by an authorized administrator of W\&M ScholarWorks. For more information, please contact scholarworks@wm.edu. 
American Studies, Cultural History, and the Critique of Culture

By Rich Lowry

College of William and Mary

\begin{abstract}
For several decades historians have expressed reservations about how scholars of American studies have embraced theory and its jargons. The program for a recent American studies convention seems to confirm the field's turn from history and its embrace of the paradigms and practices of cultural studies. The nature of this gap is complicated by comparing scholarly work published since 2000 on the Gilded Age and Progressive Era in the respective flagship journals of each field. Scholars in both fields are committed to the study of culture, but they differ in how they understand historical agency and subjectivity. A historical overview of American Studies scholars' engagement with cultural critique, and a critical analysis of how two exemplary books in the field engage with historical change, offers historians a way to understand such work not only as complementary to their own objectives, but necessary for a full understanding of the past and our relation to it.
\end{abstract}

Several years ago, I asked an old friend to join a panel on "Progressive Childhood" for the American Studies Association's annual meeting. He and I had attended graduate school together in American studies but had gone different directions once we left: he towards social and, later, public history, I towards literature and cultural studies. In our associate professorhood, however, we had found our interests converging in rewarding ways around issues of urban reform. The ASA seemed the perfect opportunity to get together.

When the panel was accepted, my friend was pleased but added that he was going "to have to let the moths out of my wallet and pony up to join" the ASA. "I dropped my membership," he went on, "a few years ago because I frankly found the AQ [American Quarterly, the association's flagship journal] shifting more and more toward incomprehensible cult crit and less cultural history." While the pun on the presumed abbreviation of "cultural" was more witty than most, my friend's complaint sounded 
familiar. I had heard similar comments from colleagues in history for decades - about how "trendy," "theory-obsessed," or "jargon-ridden" American studies had become; how scholarship in the field lacked "depth" and "rigor;" how much methodological navelgazing scholars in the field seemed to indulge in. Over the years I had risen to the field's defense, pointing to superb scholarship done by scholars working directly in the field, and suggesting that historians could do with a little more reflexive theorizing about what it is they did. But my friend's comment brought me up short: here was a fellow traveler who had distanced himself from the field he had been trained in.

The program for the convention we attended (2005) suggested that he shared his aversion to American studies with other historians. Out of over 1,200 participants on the program, only 133, just over 11 percent, identified themselves as historians. Of those, forty-nine clustered together on only twelve panels, leaving a mere eighty-four scattered among 250 other panels. And even if we grant a high percentage of historians who officially affiliate themselves with American studies programs (people like Elaine Tyler May, Ann Fabian, etc.), it does not change that the conference was overwhelmingly organized around issues of "cult[ural] crit[icism]," cultural studies, and literary studies. American studies, it seemed, was as little interested in historians as historians were in American studies.

This tendency toward critique, and presumably away from history, was all the more apparent in a subsequent (2006) issue of American Quarterly. Describing its contents, the editor Marita Sturken writes, "These are all essays that grapple with the issues of our times, the contradictions and tensions of culture, and what those contradictions can tell us about how we look at the past, how the past is entangled with 
the present, and how we understand what matters in our times. This may sound simple, but it is the essence of what we hope the journal accomplishes." ${ }^{\text { }}$ Whether or not this is the "incomprehensible" language my friend referred to, I will leave to individual judgments — in any case it is, Sturken's aside notwithstanding, far from "simple." Moreover, in its rhetoric of muscular energy (essays "grapple" with culture's "tensions," and the past is "entangled") and in its oracular presumption (note the repeated "our times"), the statement projects a stridency that one would not expect to see in, say, the Journal of American History. To be sure, Sturken accurately characterizes the issue's contents. Articles explore how the past entangles present efforts to memorialize New York City's Ground Zero, and the site of the student deaths at Kent State University. Articles on Bruce Springsteen's "Born in the U.S.A," collecting "Oriental” objects, Yiddish poetic modernism, and mestizaje culture do indeed explore the "contradictions and tensions" of understanding "what matters" (to whom, where, and for what purpose) "in our times." More to the point, the authors share with the editor a self-consciousness that manifests itself less as a reflection on method (though there is some of that) than a "grappling" both with the significance of their subject and of their work on that subject. And all of them go about their business with a frankly challenging writing style. In short, there $i$ s history being done in the issue, but it gets done with a vigorous language of cultural critique.

That said, it would be easy to make too much of the differences between American history and American studies. After all, my friend's criticism still assumes a common ground of culture between the two fields. Certainly he is right about American

${ }^{1}$ Marita Sturken, “Editor’s Note,” American Quarterly 58 (June 2006): 5. 
studies. Since its formation as an academic field in the 1940s, the most noteworthy contributions of American studies to the study of the United States have come from scholars' persistent ability to generate compelling research on the place and function of culture in the social life of the nation. ${ }^{2}$ And, for the last several decades, at least since the discipline took the "cultural" or "linguistic turn," my friend would be right to characterize American historians as equally invested in culture. To be sure, the study of culture takes place under a big tent, including as it does anthropologists, sociologists, literary critics, art historians, philosophers, as well as historians. But in my experience at least, the distance between historians and culturalists (to coin a word) has narrowed since my time in graduate school in the 1980s. Seminar debates no longer agonize over the primacy of material or meaning, base or superstructure; rather they grapple with the relative power of culture to shape perceptions and actions in history.

Daniel Wickberg has described the emergence of culture as the dominant concern of historians as both a "logical" outgrowth of the social history paradigm of the 1970s, and a "momentous" change in how history is conceived of and practiced. Whereas social historians worked to challenge the overwhelming white male perspective of the past by recovering the experiences of workers, women, African Americans, American Indians, gays and lesbians, and ethnic peoples, subsequent cultural historians, motivated by the same progressive politics, have increasingly emphasized the formation of the categories of experience — grounded in languages of race, class, gender, ethnicity, and the like - that legitimated the social hierarchies that made social history necessary. Historians, of

\footnotetext{
${ }^{2}$ In fact, Wikipedia states claims that "in the U.S. [cultural history] is closely associated with the field of American studies"; "Cultural History," Wikipedia, http://en.wikipedia.org/wiki/Cultural_history (accessed July 15, 2008).
} 
course, were not alone in re-shaping their field. A heightened sensitivity to the “constructedness" of experience, and a consequent exploration of how meaning is produced in, and produces, history and society, were the earmarks of "a larger intellectual and cultural shift" in all the humanities in the $80 \mathrm{~s}$ and $90 \mathrm{~s}$, "from immediate experience to mediated forms of representation; from agency to discourse; from social history to cultural history; from recuperation to critique; from modernism to postmodernism; or, more broadly, from freedom to necessity." ${ }^{\prime 3}$ In short, in the past decade, American historians and scholars of American studies have met on the common ground of what Raymond Williams has called "one of the two or three most complicated words in the English language." ${ }^{4}$ We are all, it seems, culturalists now.

Given these common interests - which have gone a long way towards fostering cooperation between historians and "studies" scholars in the classroom, and in building programs, as well as in scholarship — it is tempting to explain the absence of historians at the ASA on narrowly professional grounds. Perhaps in at a time of limited travel budgets the annual Organization of American Historians convention provides its members with better networking opportunities than, say, the Modern Language Association or the American Literature Association does for literary scholars, whose turn to the ASA convention tilts the conference's tone more towards "crit." Perhaps literature scholars are simply more open to cultural interdisciplinarity than historians (though my own experience suggests not). I, however, want to take historians' distance from the ASA convention as representing at least as much an act of intellectual boundary drawing as it

\footnotetext{
${ }^{3}$ Dan Wickberg, "Heterosexual White Male: Some Recent Inversions in American Cultural History," Journal of American History 92 (June 2005):140. ${ }^{4}$ Raymond Williams, Keywords: A Vocabulary of Culture and Society (1976; New York, 1983), 87.
} 
does professional expediency. It is a distance I see at times replicated in the disagreements on hiring committees for joint appointments over the relative value of good American studies and good history. And it echoes the hallway chatter I have occasionally heard encapsulated in my friend's admirably succinct phrase, "cult crit": that American studies practices (indulges in?) a scholarship so steeped in a theory-heavy jargon of "criticism" and "critique" that it threatens to corrode the complexities of culture with the simplistic and trendy jargon of "cult." These concerns arise as well in a more considered form in historians' reviews of books they are careful to qualify as American studies, and thus prone to the tortured syntax of "theory," lack of interest in the "hard" material of history, and "non-linear, associative style of thinking."

Coming as I do from the literary side of these issues, the complaint about theory sounds particularly familiar. The forty-odd year encroachment of "theory" onto the once tidy spaces of literary criticism has produced numerous conflicts over many of the same issues. My affiliation with American studies stems at least in part from my sharing with historians if not an aversion, at least a skepticism about certain manifestations of poststructuralism — including its willfully obscure language, its abstraction, and a trendiness that seems to mimic Hollywood with its star system, its love of the "blockbuster" theory, and its fetishizing of the "new." At the same time, however, I value counter-intuitive

\footnotetext{
${ }^{5}$ Akira Iriye contrasts contents of the essays in Amy Kaplan's and Donald Pease's collection of essays, Cultures of United States Imperialism with the "'hard' phenomena of "diplomacy, war, trade" in his review of the book, Journal of American History, 82 (June., 1995):.289. E Anthony Rotundo uses the second phrase to characterize Dana Nelson's method in his review of Kristin L. Hoganson, Fighting for American Manhood: How Gender Politics Provoked the SpanishAmerican and Philippine-American and Philippine-American Wars, and Dana D. Nelson, National Manhood: Capitalist Citizenship and the Imagined Fraternity of White Men, Journal of American History, 86 (March, 2000) 1818. My ear detects a gendering here that characterizes history as masculine and American studies as feminine.
} 
inquiry for its skeptical prodding of the blindness and contradiction of "common sense" and its challenge to the limits and vanities of intellectual orthodoxies. I also understand that at times difficult questions call for difficult language. To be sure, this kind of selfreflexivity can be daunting enough to tempt anyone to bracket theory just "to get the job done." But given that such questions have persisted for nearly half a century not just in academe, but as well in the broader culture, we would fulfill poorly our obligations as intellectuals if we simply ignore them.

All that aside, however, American studies is not post-structural, nor is it simply the national brand of cultural studies - though its arc of influence has roughly coincided with that of critical theory. It does, however, remain a field where many of those theoretical and political questions — fuel to the engine of critique — are brought productively to bear on the study of history. Which is why, inspired by my friend's criticism, and mindful of the complex relations between cultural history and culturalism, I would like to act as a skeptical emissary for a field that has as much to offer historians as it has to learn from them. My motives here are complicated. As someone who makes his intellectual home in American studies, I value deeply the interdisciplinary combustion of historical inquiry and cultural critique that for me characterizes the best work in the field. And while I have no doubt that American history and American studies can get along just fine the way things are, a better understanding of both the possibilities and limitations of culture critique in the practice of history seems to me to promise a richer and finally more productive dialog over issues we all share interest in. And maybe I will see more of my historian friends at ASA conventions. 
Another motive stems from my conviction that the problem of history and culture is particularly important to the study of the Gilded Age and Progressive Era. It is largely a matter of origins. First of all, it was of course during this period that we find the formation of those academic disciplines such as history, literature, sociology, and anthropology that continue today to define our study of the nation. Secondly, the discourses and institutions of professional knowledge formed dialectically with an even more profound social reorganization of culture in the form of what we have come to call mass culture - changes in how and to what purposes culture was produced, disseminated, experienced, and consumed; in who partook in these processes; and to what ends. In short, as Alan Trachtenberg recognized in The Incorporation of America (1982), the decades roughly between the Civil War and the 1920's mark an extended "turning point" in the history of the nation that yielded much of the society and culture we recognize as our own. ${ }^{6}$ Thus, to borrow Sturken's words in $A Q$, how we "grapple" with "the contradictions and tensions of culture" at the turn of the twentieth century "can tell us about how we look at the past, how the past is entangled with the present, and how we understand what matters in our times" and, I might add, how we understand what mattered in times past.

I have encountered this historical uncanniness when "grappling" with texts like Mark Twain's Connecticut Yankee. Even as Twain grounded his historical fantasy in the

\footnotetext{
6"Turning point" comes from Alan Trachtenberg, "The Incorporation of America Today," American Literary History 15(Winter 2003): 759. The article responds to a forum on Trachtenberg's book. Others of course have made this claim as well. Among the more influential are Robert Wiebe, The Search for Order, 1877-1920 (New York, 1967); Stuart Hall, "Notes on Deconstructing the Popular" in People's History and Socialist Theory, ed. Raphael Samuel (London, 1981), 227-40, and Martin J. Sklar, The United States as a Developing Country: Studies in U.S. History in the Progressive Era and the 1920s (New York, 1992).
} 
industrial and post-Reconstruction turmoil of the nineteenth century, he also seemed to anticipate a future not only of "new deal" politics (Twain's second-most famous coined phrase, following of course "the gilded age"), but, as I have found recently in the classroom, of the disastrous hubris of contemporary American nation-building. My best response to this apparently synchronic resonance which runs through much of his work (one need only compare his writing with, say, that of Melville, to recognize a certain contemporaneity in Twain's voice), is to understand it both of the moment of the Gilded Age, and grounded in a shared our times that includes both his and my culture and is shaped by historically continuous dynamics of domestic race relations, international violence, technology, and reform. Twain's writing does not anticipate the future in any prophetic way; rather, his immersion in his culture produced a vision and a language we recognize as ours.

Another point about Twain ties his work to my motives for writing. It is not just historical coincidence that his novel of nation-building would be told in the voice of a "Yankee of Yankees" that anticipated by only a few years the equally fictional, if more carefully historicized, figure of the frontier hero imagined by Frederick Jackson Turner, in his bid at the Columbian Exposition to make nation-building the central paradigm of American history. Nor is it coincidence that both Turner and Twain saw their narratives of the past at least in part as critical contributions to a public discussion on nationhood. In short, in these two practitioners of critical history we can see not only the origins of our own scholarly enterprises today, but as well a suggestion that history and critique at their best operate hand-in-hand. 
So this essay represents a small effort at bridging, or at least making visible, a border between cultural history and "cult crit" that may in fact have been more permeable in the Gilded Age. To do so I will offer my own critique, and a bit of history, of American studies. To begin, I will compare how scholars in the leading journals in American history and American studies engage the problem of culture in the Gilded Age and Progressive Era. My aim here is less to draw a border than to use these differences to characterize the interests, assumptions, and tendencies of scholars of historical culture working in American studies - a field notorious for its lack of coherence. I will then offer a sketch of the historical culture of critique within American studies, with a particular eye on how both the myth and symbol school of the mid-twentieth century, and the field of cultural studies, shape contemporary issues in the scholarship. Finally, I will end the essay by turning to two books that exemplify the tendencies I describe, texts that over the last five years, by many accounts, have played an important role in shaping the discussion about one of the more pressing topics of the 1860s-1910s: empire and the incorporation of non-Anglo peoples and cultures into a national hegemony. The first, Laura Wexler's Tender Violence (2000), takes as its subject the work of several women photographers, who unexpectedly provide a window into how sentimental domesticity shaped the culture of U.S. imperial expansion during the late nineteenth and early twentieth centuries. ${ }^{7}$ The second, Amy Kaplan's The Anarchy of Empire (2002), more broadly offers ways of

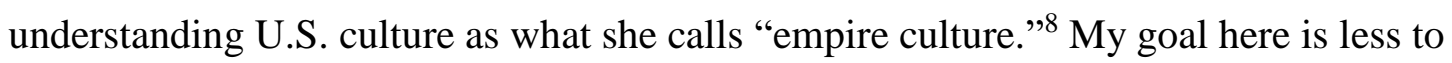

${ }^{7}$ Laura Wexler, Tender Violence: Domestic Visions in an Age of U.S. Imperialism (Chapel Hill, 2000).

${ }^{8}$ Amy Kaplan, The Anarchy of Empire in the Making of U.S. Culture (Cambridge, MA, 2002). 
review some of the best work in the field than it is to suggest a way to read it

productively.

Throughout, even as I make clear the limits and contradictions of how American studies engages history and culture, I contend that it is precisely because it encourages "cult crit," that the field plays a vital role in our production of knowledge about the past. Particularly important is its role as history's disciplinary unconscious - a field of dialog, questioning, even speculation that supplements, even as it challenges, contemporary historical practice. In one sense, then, American studies depends on history, just at it does on the other disciplines it borrows from and critiques, much as a parasite does its host. Or perhaps a better metaphor would describe the field as given to disciplinary poaching. ${ }^{9}$ The "recurring angst" of American studies graduate students about the field's unclear aims and method that Bruce Kuklick noted in the 1960s continues today because the field borrows its methods from sibling disciplines. ${ }^{10}$ As Michael Denning and Robert Sklar have argued, this unfocused and finally untheorized pragmatism has its problems. ${ }^{11}$

Others, however, have found this lack of center gives the field a wide-open quality that historian Patty Limerick, for one, finds liberating: "Thank heavens," she said in her 1996

\footnotetext{
9Gene Wise first suggested American studies had become "something of a 'parasite' field-living off the creations of others" in his 1979 essay, "Paradigm Dramas' in American Studies: A Cultural and Institutional History of the Movement," American Quarterly 31 ([THERE IS SIMPLY NO MONTH, NADA, 1979): 315. Michel de Certeau first introduced the term "textual poaching" in The Practice of Everyday Life (Berkeley, 1984) to describe how readers make use of texts in ways that ignore, and even run counter to the prescribed use. Henry Jenkins expanded the concept in his discussion of the politics of cultural fandom in Textual Poachers: Television Fans \& Participatory Culture (New York, 1992).

${ }^{10}$ Bruck Kuklick, "Myth and Symbol in American Studies," American Quarterly 24 (Oct. 1972): 435.

${ }^{11}$ Michael Denning has echoed Robert Sklar's [1975] lament about the "poverty of theory in American studies." See Denning, “"The Special American Conditions': Marxism and American Studies," American Quarterly, 38 (SAME AS THE WISE ARTICLE 1986): 372, and Robert Sklar, "The Problem of an American Studies 'Philosophy': A Bibliography of New Directions," American Quarterly, 27 (Aug. 1975): 245-62.
} 
ASA presidential address, "for American studies: the place of refuge for those who cannot find a home in the more conventional neighborhoods, the sanctuary of displaced hearts and minds, the place where no one is fully at ease....The joy of American studies is precisely in its lack of firm limits and borders." 12

1.

Limerick's celebration of a Turneresque intellectual frontier notwithstanding, I would like to scout the border between American history and American studies with a brief survey of recent work on the Gilded Age and Progressive Era appearing in the leading journals in both fields. Immediately Wickberg's claim for the dominance of culture is confirmed. Since 2000, American Quarterly has published twenty-three research articles roughly on the Gilded Age and Progressive Era; virtually all of them forthrightly engage the production and dissemination of meaning and its effects on social life and subjective experience. During the same period the Journal of American History and the American Historical Review together published eighteen articles on the period, of which fourteen could be said to be directly concerned with the historical production and effects of culture. ${ }^{13}$

Within this sample, cultural inquiry in all three journals focuses on remarkably similar issues: the emergence of a recognizable modernity in new market relations and commodities, sexuality, cosmopolitan urbanization, mass cultures, and in new structures

\footnotetext{
${ }^{12}$ Patricia Nelson Limerick, "Insiders and Outsiders: The Borders of the USA and the Limits of the ASA: Presidential Address to the American Studies Association, 31 October 1996," American Quarterly 49 (Sept. 1997): 452-55

${ }^{13}$ For purposes here, I count only scholarly articles and do not include reviews and review essays in the total.
} 
and experiences of identity; what could be called the histories of nomenclature, particularly as manifested in collective categories of race, masculinity, sexuality, ethnicity (instead, or alongside of, histories of women, African Americans, Chinese, and men). The most marked trend in research is the attempt to resituate national history and experience in "transnational," "comparative," "global," and "imperial" contexts, reminding us both of the deep investment in nationhood shared by historians and culturalists alike, and of how that investment has emerged as a persistent challenge to current scholarship. Finally, the overall convergence of interests and approaches is emphasized by how easily a number of articles could have appeared in either $A Q$ or $J A H$, including Thomas Hickman's on narcotic addiction and models of identity and Jürgen Martschukat's investigation of how the electric chair sparked a modern discourse of the sublime, both of which appeared in JAH, or Christina Duffy Burnett's article on the American Guano Islands and national sovereignty and Nayan Shah's account of western states' court cases, Asian and native Anglo men, and homosexuality, both in $A Q .{ }^{14}$ From this perspective, whatever border there is between discipline and field remains distinctly open.

A closer look, however, refines this perspective: if culturalists and historians cover similar terrain, they seem to do so with very little reference to each other's maps. Of the eighteen articles in the history journals, only five cite material from American

\footnotetext{
${ }^{14}$ Christina Duffy Burnett, "The Edges of Empire and the Limits of Sovereignty: American Guano Islands," American Quarterly 57 (Sept. 2005): 779-803; Thomas Hickman, "'Mania Americana': Narcotic Addiction and Modernity in the United States, 1870-1920," Journal of American History 90 (Mar. 2004): 1269-94; Jurgen Martschukat, “"The Art of Killing by Electricity': The Sublime and the Electric Chair," Journal of American History 89 (Dec. 2002): 900-21; Nayan Shah, "Between "Oriental Depravity" and "Natural Degenerates": Spatial Borderlands and the Making of Ordinary Americans," American Quarterly 57 (Sept. 2005): 703-25.
} 
Quarterly, while ten refer to work in either $J A H, A H R$, or both. Even more notably, only three of the twenty four articles in $A Q$ cite anything published in $J A H$, while only one cites a 1933 piece from $A H R$. This lack of attention to work in $J A H$ is particularly notable in Maria Farland's 2007 essay in $A Q$ on “W. E. B. DuBois, Anthropometric Science, and the Limits of Racial Uplift," which makes no reference to Axel Schäfer's 2001 JAH article, "W. E. B. Du Bois, German Social Thought, and the Racial Divide in American Progressivism, 1892-1909"- this despite their mutual interest in DuBois's struggle to explicate the capacity of African Americans for cultural and social uplift. ${ }^{15}$ I do not want to overemphasize the significance of this - there are too many reasons, including simply questions of length, for trimming citations, to draw specific conclusions from specific omissions - beyond pointing out that whatever role Shafer's work may have (or have not) played in Farland's thinking, it was not considered part of her scholarly dialog.

Citation practice can also tell us more about how American studies and American history function as scholarly fields. Farland's is among only nine $A Q$ articles—just over a third of our sample - that bother even to cite work from that journal. In other words, unlike historians — or for that matter most scholars writing in a humanities discipline—it seems from our admittedly small sample here, that culturalists feel little urge to frame their arguments with reference to previous work in American studies on their topic, much less in history. This tendency may simply reflect the interdisciplinary nature of American studies: if historians, literary scholars, art historians, and legal scholars (to name a range of writers in our $A Q$ sample) $d i d$ frame their work with reference to their fields, there

\footnotetext{
${ }^{15}$ Maria Farland, "W. E. B. Dubois, Anthropometric Science, and the Limits of Racial Uplift," American Quarterly 58 (Dec. 2007): 1017-44; Axel R. Schafer, "W. E. B. Du Bois, German Social Thought, and the Racial Divide in American Progressivism, 1892-1909," Journal of American History 88 (Dec. 2001): 925-49.
} 
would be little overlap in citations. Instead, they would situate their work in more theoretical or trans-disciplinary discourses like feminism or race studies. In the case of Alan Braddock's essay on the painter Thomas Eakins, the anatomy professor, William Forbes, and the "Anatomical Fraternity in Postbellum Philadelphia," an American studies scholar could draw on theories of the body to describe the uncanny mixture of life in death in human body parts. ${ }^{16}$ I think, however, these different citation practices point to a more complex and fundamental difference between American history and American studies.

When historians of culture, as they generally do in our sample, frame their research and arguments by pointing to an inadequacy in the relevant historiography to explain an anomaly, contradiction, or pattern in the historical record, they not only act to consolidate the discourse of the discipline, they also work to integrate culture into what is seen as the larger field of history. Take, for instance, Hickman's 2004 study of drug addiction at the turn of the twentieth century in $J A H$. After reviewing "contributions to the historical study of drug use and policy in the United States," he offers his study as "a close analysis of the way the addiction concept figured within its broader cultural context" as a necessary addition to our understanding of how and why addiction emerged as a moral panic in the late nineteenth century. ${ }^{17}$ Addiction, he goes on to argue, was part of the larger culture of crisis that characterized the era's response to what we have come to call modernity. Similarly, in a 2002 issue of $J A H$, Louis Warren uses the occasion of the social contact between Bram Stoker and Buffalo Bill Cody in London to open out a

\footnotetext{
${ }^{16}$ Alan C. Braddock, “'Jeff College Boys': Thomas Eakins, Dr. Forbes, and Anatomical Fraternity in Postbellum Philadelphia," American Quarterly 57 (June. 2005): 355-83.

${ }^{17}$ Hickman, “'Mania Americana': Narcotic Addiction and Modernity in the United States, 1870$1920, " 1271$.
} 
provocative and subtle exploration of how the "shadowy connections" between Stoker's novel Dracula, and Buffalo Bill's "Wild West Show" point to the "darker twin" of the "the triumphalism of America's frontier myth": "the contemporary fear of the frontier as a place of racial monstrosity." "New western historians," he goes on to argue, "have evaluated the nostalgia of the frontier myth in light of the darker and more complicated events of history but have yet to explore fully the deep-set fears of the West among the white victors." 18 Both articles represent sophisticated efforts at integrating cultural dynamics into broader historical perspectives. At the same time, however, both of them do so by using language that, oddly, suggests that culture is somehow outside of, or at least different from, history. Hickman implicitly distinguishes his "analysis...of cultural context" from "historical study," while Warren contrasts the "complicated events of history" with the presumably simpler, yet (as he makes clear) important, workings of myth.

Culturalists writing in $A Q$, on the other hand, manifest little anxiety over or even interest in the tensions between history and culture. I think it is safe to say that in the American studies scholarship represented in $A Q$, culture is the site of history. This tendency emerges explicitly in Dana Seitler's 2003 analysis of Charlotte Perkins Gilman's writings and the gender politics of motherhood, early twentieth-century eugenics, and theories of racial degeneration. "If some of the greatest anxieties over cultural progression of this period were organized around theories of heredity," she asks, "what kinds of pressures, urgencies, or appeals were placed on the category of motherhood, and how did women-authored narratives or feminist rhetorics react to or

\footnotetext{
${ }^{18}$ Louis S. Warren, "Buffalo Bill Meets Dracula: William F. Cody, Bram Stoker, and the Frontiers of Racial Decay,” American Historical Review 107 (Apr. 2002): 1130.
} 
participate in the generation of these appeals? The figure of the mother emerged with new meaning and significance at the fin de siècle as a fantasy of moral idealism, a symbol of a quintessential American identity, and, moreover, as a privileged site of material and biological value." 19 In some ways, Seitler mines the same cultural vein as Warren, albeit with different tools — she explores "ideologies" rather than "myth," and uses literary terms like "figure," "symbol," rather than the more intellectual historical term "concept," to explore its components. For her, however, history takes place inside culture: "rhetorics react to or participate in" making ideology; the mother figure establishes "material and biological value" [emphasis added].

Clearly Seitler presumes a much more active role in social change for culture than do Hickman and Warren-a perspective she shares with most of her fellow contributors to $A Q$. We can understand this divergence in a number of different ways. On one level, we can say that cultural historians like Warren and Hickman and culturalists like Seitler complement one another by studying different moments in the immensely complex and open-ended feedback loop of culture designated roughly by the term "socially constructed." Culturalists focus on the extent to which culture shapes who we are and what we do, while cultural historians are more sensitive to how what we do and who we are produce culture. Thus the difference could be see as lying in the choice of objects: the historical discourses of culture or the historical uses of culture. In the end, however, complementarity does not account for how divergently Seitler and Warren understand people and historical change. To put the matter a bit too crudely, Warren uses the language of agency while Seitler uses the language of the subject. People in Warren's

\footnotetext{
${ }^{19}$ Dana Seitler, "Unnatural Selection: Mothers, Eugenic Feminism, and Charlotte Perkins Gilman's Regeneration Narratives," American Quarterly 55 (Mar. 2003): 62.
} 
world, and in the world he addresses, do things with culture. From this perspective, it makes sense to differentiate history (the world of "doing things"), from culture (the object of doing). In Seitler's world, people are subjects of and subjected to the powerful meanings of culture which circulate as it were not so much above social life as through it, shaping not only perception but subjectivity as well—not only who we are but how we think we know who we are - and thus shaping how we act. Individual action is so suffused with meaning-linguistic, visual, material (the build environment), and institutional (the means whereby knowledge is produced, legitimated, and put into action) — that it makes sense to talk about "rhetorics reacting."

Flowing from these diverging emphases are equally varied relationships of the researcher to the object of study. Wickberg suggests this when he notes that the shift from social to cultural history has brought about changes in attitude: sympathetic engagement, even identification with the struggles of subaltern groups of the past tends to be replaced with a theoretically informed critical distance informing analyses of socially constructed categories and meanings. ${ }^{20}$ Seitler, for example, is more interested in motherhood than mothers. In light of our comparison here I would suggest he overstates the difference between historians, but perfectly characterizes that between scholars of cultural history and cultural critique. At stake for agentists are the struggles of individuals and groups to live the kind of lives they want in an often challenging, even difficult social world; at stake for culturalists is the critical analysis of how cultures offer possibilities even as they foreclose others for social and individual change.

\footnotetext{
${ }^{20}$ Wickberg, "Heterosexual White Male," 150.
} 
Certainly these divergent interests and emphases begins to account for whatever gaps and tensions there are between American history and American studies, and between cultural history and "cult crit." At the same time, however, I assume at this point that these differences are recognizable to anyone trained in history as precisely problems of history. E.P. Thompson's attack on "the poverty of theory" aside, "critique," "analysis," "theory," and "interpretation"—as historians from Hayden White and Dominick La Capra, to Ann Stoler, Joan Scott, and Saul Cornell have made clear-are tools and practices central to the practice of studying the past. ${ }^{21}$ In other words, American studies is as much a necessary part of history as history is of American studies. In characterizing American studies as jargoned, theoretical, and too self-reflexive, historians are making extrinsic a discourse that is intrinsic to what they do. Characterizing American studies as the exception that proves the rule mis-recognizes how much the rule depends on the exception for its legitimacy.

Much the same point can be made about American studies. When historians persist in holding onto distinctions between doing history and analyzing culture they reproduce splits between material and ideas, base and superstructure, body and mind; when studies scholars wholeheartedly embrace culturalism they risk not just engulfing, but replacing the specificity of social life embedded in particular places, times, and

\footnotetext{
${ }^{21}$ Needless to say, the range of engagement with theory by White, LaCapra, Stoler, and Scott is remarkable. Most relevant here is Hayden White, The Content of the Form: Narrative Discourse and Historical Representation (Baltimore, 1987), Dominick LaCapra, Soundings in Critical Theory (Ithaca, 1989), Ann Stoler, "Tense and Tender Ties: The Politics of Comparison in North American History and (Post) Colonial Studies," Journal of American History. 88 (Dec., 2001): 829-865, and "Matters of Intimacy as Matters of State: A Response," Journal of American History 88, (Dec., 2001): 893-897, Joan Scott,"The Evidence of Experience," Critical Inquiry 17 (Summer, 1991): 773-797. See also Saul Cornell, "Moving beyond the Great Story: Post Modern Possibilities, Postmodern Problems," American Quarterly 50 (June, 1998): 349-57. E. P. Thompson, The Poverty of Theory and Other Essays (London, 1978).
} 
peoples, with a web of relative significance and representation. ${ }^{22}$ As Patrick Brantlinger has put the issue, the problem with culture is that "there is nothing that is not culture - a totalizing definition that (like other totalizing definitions of society, ideology, or history) excludes nothing and, hence, explains nothing., ${ }^{, 23}$ This yields, paradoxically enough, a tendency to instrumentalize all culture as the site, or vehicle, for power. Wickberg notes "the centrality" to American culturalism "of issues of power, hegemony, and domination, on the one hand, and agency, resistance, and complicity, on the other." As such "meaning is an instrument of domination or resistance." 24 However, without an understanding of how conflict and power (a dangerously reified term in its own right these days) can operate outside of culture, and equally important, how and when culture operates outside of power, culturalists risk simply rewriting human experience as allegorical supernarratives of, say, racial oppression and subversion or of masculinity always in crisis.

Thus it seems that the historians who sit on the sidelines of the ASA, and the culturalists who make little effort to include them in their discussion, risk missing the extent to which history and American studies supplement the questions and interests each brings to historical cultural studies. We need this critical dialog simply to make sense of what we do. Each of us, in producing knowledge of the past, produces, and reproduces

\footnotetext{
${ }^{22}$ On distinctions in history, see Richard Handler "Cultural Theory in History Today," American Historical Review 107 (Dec., 2002): 1513-20..

${ }^{23}$ Patrick Brantlinger, "A Response to Beyond the Cultural Turn," American Historical Review 107 (Dec. 2002): 1503.

${ }^{24}$ Wickberg, "What Is the History of Sensibilities? On Cultural Histories, Old and New," American Historical Review 112 (June, 2007): 673.. On hegemony, see T. J. Jackson Lears, "The Concept of Cultural Hegemony: Problems and Possibilities," American Historical Review, 90 (June 1985): 567-93; and Paul Lauter, From Walden to Jurassic Park: Activism, Culture, and American studies (Durham, 2001), 18.
} 
culture of the moment. How we understand that culture - what it is, how it works, why it matters-shapes how we approach critique. No "crit," no "cult."

It is tempting to date the emergence of American studies's culture of critique from the infusion of poststructuralism in the humanities beginning in the 1970s. In fact since the early twentieth century, when Americanists were more likely to refer to "civilization" instead of culture, and certainly since the emergence of American studies as an academic field in the 1950s, critique has held as central a place as culture in the American studies project. In part this critical tendency grows from its roots in interdisciplinarity. As early as 1957, Henry Nash Smith, one of the founding figures of the academic discipline, critically evaluated the limits of literary criticism, sociology, and cultural anthropology in the effort to formulate "a method of analysis that is at once literary ... and sociological." ${ }^{25}$ In the last several decades, however, even as the term "interdisciplinary" remains at least as popular as it once was, within American studies this notion has lost much of its power to encourage methodological reflection and innovation. Indeed my survey of the last eight years of $A Q$ yielded substantially less attention to methodological issues than $\mathrm{I}$ found in $J A H$ and $A H R .^{26}$

What has most energized the field over the past four decades is what Alan Trachtenberg has characterized as the blend of "critical cultural history" and "pedagogical activism": Americanists, he argues, have been active in "“reshaping ... the

\footnotetext{
${ }^{25}$ Henry Nash Smith, “Can ‘American Studies' Develop a Method?” American Quarterly 9(Summer 1957): 201. ${ }^{26}$ One very fine exception to this would be Larry J. Griffin and Maria Tempenis, "Class, Multiculturalism, and the American Quarterly," American Quarterly 54 (Mar. 2002): 67-99.
} 
collective culture in the act of studying and criticizing it." ${ }^{27}$ More recently, Paul Lauter, best known for his pioneering of the multicultural Heath Anthology of American Literature, has put the matter more bluntly: "doing American studies is a political act." For him, "American studies can most usefully be understood... as a framework within which people engage in those most significant of intellectual ventures, changing or policing the society in which they live." ${ }^{28}$ So pervasive is this linking of scholarship, teaching, and social praxis that in his presidential address to the ASA in 2007, Emory Elliott could assume, "I am no exception in having come to American studies out of political convictions." Speaking with a deep sense of urgency "[i]n this time of deep political division, national paranoia, and global uncertainty," concerned about political pressures against academic freedom and free speech, Elliott calls on "scholars...across the globe...to broaden the range of ideas needed to bring about change." 29 As such, all three scholars envision American studies as a complex dialectic of pedagogy and research, of intellectual endeavor and progressive politics. During the 1990s critique most notably focused on questions of identity; even today, as Michael Millner has pointed out, “identity, in its most sophisticated anti-essentialist, revisionist forms...is still very much a fundamental lens for knowledge production" in the field. ${ }^{30}$ This intellectual attention

\footnotetext{
${ }^{27}$ Quoted in Joel Pfister, "The Americanization of Cultural Studies," Yale Journal of Criticism 4 (Spring 1991): 212.

${ }^{28}$ Lauter, From Walden to Jurassic Park, 2, 65.

${ }^{29}$ Emory Eliott, "Diversity in the United States and Abroad: What Does It Mean When American studies Is Transnational?" American Quarterly 59 (Mar. 2007): 2-3.

${ }^{30}$ Michael Millner, "Post Post-Identity," review of Walter Benn Michaels, The Shape of the Signifier: 1967 to the End of History and Kenneth Warren, So Black and Blue: Ralph Ellison and the Occasion of Criticism, American Quarterly 57 (June, 2005): 542 On p. 541, Millner also notes a current "sense of exhaustion around the whole project of identity." For a current engagement with identity studies, see Vicki L. Ruiz, "Citizen Restaurant: American Imaginaries, American Communities," American Quarterly 60 (Mar. 2008): 1-21. Lauter, Walden to Jurassic Park, voices a particularly strong sense of affinity between American studies and identity studies programs.
} 
fostered an activism very similar to the identity politics grounding such programs as women's studies, African American studies, American Indian studies, and ethnic studies. Indeed, for well over fifteen years, American studies has intellectually and institutionally embraced the identity paradigm. And despite tensions between programs over institutional resources and intellectual ownership, identity studies continues to offer powerful possibilities for pedagogical and community activism. ${ }^{31}$

Alongside these efforts there have arisen concerns about the present political climate for scholarship like those expressed by Elliott. A few years before Elliott's address, Michael Berubé, in a 2004 article in $A Q$, developed these issues more fully. Given the current global crisis and the domestic dominance of conservatism, in which in “the Bush lexicon, it would appear, the phrase 'loyal opposition' is filed under 'oxymorons,' as if the interests of the Bush-Cheney White House were coextensive with the parameters of patriotic political speech in the United States"; and given that “American studies has been closely identified with the political left," Berubé uses his essay to ask, “just what kind of ‘American' values American studies might plausibly remain loyal to, if in fact we do not want (as I presume we will not want) to be reconfigured as a scholarly adjunct to a neoimperialist foreign policy." 32 In asking such a

\footnotetext{
${ }^{31}$ On difficulties between programs, see David Goldstein-Shirley, "American Ethnic Studies, or American Studies vs. Ethnic Studies?," American Quarterly 54 (Dec. 2002). On identity and pedagogical activism, see Lois Palken Rudnick, Judith Smith, Rachel Rubin, Eric Goodson, and Carol Siriani, "Teaching American Identities: A University/Secondary School Collaboration," American Quarterly 54 (June 2002): 255-77.

${ }^{32}$ Michael Berubé, "The Loyalties of American studies," American Quarterly 56 (Jun. 2004): 22326. For reasons too complex to go into here, outside of the United States, American studies has occupied a wider political spectrum. See Gunter H. Lenz, "Towards a Dialogics of International American Culture Studies: Transnationality, Border Discourses, and Public Culture(s)," in The Futures of American Studies, ed. Donald Pease and Robyn Wiegman (Durham, 2002), 461-85, and Allen F. Davis "The Politics of American Studies," American Quarterly 42 (Sept., 1990): 353-74.
} 
question, Berubé presumes a key ingredient to the nature of critique in the field: at stake in American studies scholarship are national values. ${ }^{33}$ On this point, if on few others, he agrees with Alan Wolfe, who in a 2003 review of new Americanist scholarship, charges scholars with abjuring their obligations to national values by perpetrating an "antiAmerican studies." Conjuring images of Stalinism, he characterizes debates within American studies over nation, history, class, and race as a relentless process of leftist purge that consolidates itself around an increasingly pure radicalism grounded in "a hatred for America so visceral that it makes one wonder why they bother studying America at all." 34

Wolfe tends towards caricature in expressing his own visceral hatred of the excesses of "cult crit," but he takes the task of critically engaging national values every bit as seriously as those he attacks. In his vehemence, however, he misses what Berubé, borrowing from Leo Marx, describes as the "doubleness" of the adversary culture from which American studies draws its energy. Marx is one of the founding figures of academic American studies whose study of literary and painterly responses to the impact of technological modernity, Machine in the Garden (1964), appeared in what Wolfe calls "the golden age" of American studies and remains a classic in the field. ${ }^{35}$ Reflecting on a career spanning over five decades as one of its central figures, Marx acknowledges that "the view of the United States held by most of the founding generation of American

\footnotetext{
${ }^{33}$ Denning, "'Special American Conditions,"”360, argues that "the founding question of the discipline remains 'What is American?"'

${ }^{34}$ Alan Wolfe, "The Difference between Criticism and Hatred: Anti-American Studies." The New Republic, Feb. 10, 2003, 26. The earliest use of the term came in Kenneth Lynn, review of T.J. Jackson Lears No Place of Grace, New York Times Book Review (Jan. 10, 1982): 29.

${ }^{35}$ Wolfe, "Difference Between, 25. Wolfe is not alone in this language; Wise in "Paradigm Dramas," "308, terms the mid-twentieth century "the Golden Era." Leo Marx, The Machine in the Garden: Technology and the Pastoral Ideal in America (New York, 1964).
} 
studies scholars embodied much of the Left's radical skepticism — not to say hostility— toward the capitalist system." However, alongside at times strident critiques of capitalism, early American studies scholars also proclaimed "a passionate reaffirmation of the egalitarian Enlightenment principles of the American Revolution." Thus the "doubleness" of an "adversary culture" that reaches at least back to abolition, flourished in "the shadowy borderland between Academia, Bohemia, and Grub Street" as part of the 1930s Popular Front, erupted during what Marx calls "the Great Divide" in the 1960s, and continues today. Even as scholars levy "harsh criticism" at the United States, they affirm their "anxious affection for the world's first and largest experiment in multicultural democracy." At the heart of any American studies scholar lies "this intensely personal, essentially political, morally ambiguous motive" of "believing in America." 36

This "doubleness" is clearly visible in one of the field's exemplary texts: Henry Nash Smith's The Virgin Land, published in 1950. In this expansive book (which is still in print) Smith concerns himself with how representations of the West—as paradisiacal Nature, as a passage to the Far East, as a garden for the nurture of democracy—helped nineteenth-century Americans imagine themselves collectively as a distinct nation. To make his argument, Smith drew on an impressive array of sources, diaries, letters, oratory, novels, poetry, popular journalism, and dime novels, to tease out what he called

\footnotetext{
${ }^{36}$ Leo Marx, "On Recovering the 'Ur' Theory of American Studies," American Literary History 17 (Spring, 2005): 121, 26, 28. Berubé cites an earlier version of the article, "Believing in America: An Intellectual Project and a National Ideal," Boston Review 28 (Dec. 2003-Jan. 2004), http://bostonreview.net/BR28.6/marx.html. I should note that this faith applies primarily only to those from the United States. On the cultural politics of the Popular Front, see Michael Denning, The Cultural Front: The Laboring of American Culture in the Twentieth Century (New York, 1998). On the early history of American studies, see Allen Davis, "Politics of American Studies," and Wise, "'Paradigm Dramas."”
} 
elsewhere "the subjective life" of the American character, a concept he borrowed from Frederick Jackson Turner. ${ }^{37}$ Smith's goal, as he put it in the preface, was to map the myths and symbols that shaped the nation, and to uncover the "intellectual construction[s] that [fused] concept and emotion into an image." While the materials he looked at were produced by individuals — Thomas Jefferson, Whitman, Turner-Smith was most concerned with their function as "collective representations." They may not “accurately reflect empirical fact." Indeed, they operated on an altogether "different plane," but they nonetheless exerted "a decided influence on practical affairs.",38 In suggesting a split between "empirical fact" and the "different plane" of representation, Smith anticipates how Warren-who uses "myth" to describe a frontier culture motile enough to circulate even in London-separates history from culture. ${ }^{39}$ Overall, however, Smith's understanding of his sources as what he elsewhere calls "individual instances" of larger cultural "uniformities" associates his work more closely with the "subject" approach of culture practiced by Seitler. ${ }^{40}$ Indeed, what gives his book its "legs," to borrow publishing jargon, is how fully it embodies the abiding ambition in American studies to engage cultural totality while eschewing any sustained commitment to social structure. Culture, in Smith's mind, designated that web of significance that linked any single node to the larger whole. ${ }^{41}$ Thus, as Alan Trachtenberg did with the

\footnotetext{
${ }^{37}$ Henry Nash Smith, The Virgin Land: American West as Symbol and Myth (New York, 1950), 197.

${ }^{38}$ Smith, "Preface," p\#?

${ }^{39}$ Warren cites Smith's book, though he draws more fully on Richard Slotkin's Regeneration Through Violence: The Mythology of the American Frontier, 1600-1860 (Norman, OK, 1973),, which he also cites.

${ }^{40}$ Smith, “Can 'American Studies' Develop a Method?” 208.

${ }^{41}$ Clifford Geertz's influential essay, "Thick Description: Toward an Interpretive Theory of Culture," in The Interpretation of Cultures: Selected Essays (New York, 1973), 3-30, draws on Max Weber to suggest that "man is an animal suspended in webs of significance he himself has
} 
Brooklyn Bridge, culturalists could practice a form of interpretive synecdoche by investigating particular texts, objects, myths, and symbols for what they revealed about the social whole that was not readily visible. ${ }^{42}$

Embedded in this practice was an assumption about what this broader culture looked like. Like his peers of "the golden age," David Potter in The People of Plenty (1954), Louis Hartz, in The Liberal Tradition in America (1955), R.W.B. Lewis in The American Adam (1955), and Marx in Machine in the Garden (1964), Smith argued for the existence of "an American Mind," a complex, but "more or less homogeneous" sensibility that arose from the unique circumstances of the New World, endured over time, was theoretically found in all forms of culture, but was best seen in complex works produced by a canon of Anglo male writers. ${ }^{43}$ By the very fact of her choosing to write on Charlotte Perkins Gilman, as well as her conceptualization of nation and culture as sites of contradiction, struggle, and diversity, Seitler signals how much contemporary culturalism is invested in a culture of diversity and contestation. At the same time, however, Seitler presumes a cultural totality linked more to be sure by power and resistance than by common myths and symbols, but nonetheless visible as a whole at numerous points. At the same time she continues the effort first begun by Smith, Marx, and their peers to expand the study of the past to include such materially ineffable but powerful forces as the fusion of "concept and emotion," of representation and subjectivity, and of culture and historical change.

spun" (5). Geertz's essay appeared after Nash's book but offered an interpretation of culture that complemented that in Virgin Land.

${ }^{42}$ Alan Trachtenberg, Brooklyn Bridge: Fact and Symbol (Chicago, 1965).

${ }^{43}$ Wise, "'Paradigm Dramas," 306. Wise notes that the textbook for one of the earliest American studies courses was entitled, simply, The American Mind. 
I would also hazard that Smith and Seitler would share a common relationship to the history they produce, agreeing that the past, " how we look at the past, [and] how the past is entangled with the present" (to quote Sturken), are part of the same story. In other words, Smith's understanding of history and culture implicated his own work in the process of national formation he was studying. Smith signals this critical engagement early on when he paraphrases J. Hector St. John de Crèvecoeur's question, first asked in the third of his Letters from an American Farmer (1782), "What then is the American?"44 Grounded in his sense that new social conditions apart from "ancient prejudices and manners" of Europe promised "a new race of man, whose labors and posterity will one day cause great changes in the world," Crèvecoeur's question was part colonialist fantasy (this "new race" drew strictly from Western European heritage) and part social idealism (it might nonetheless foster a utopian democracy). Thus in raising it as he did after independence and before the ratification of the Constitution, Crèvecoeur sought to discover a cultural identity more fundamental than, because it precedes, a political entity - an inquiry subsequently taken up by the likes of Tocqueville, Emerson, Margaret Fuller, Frederick Douglass, Whitman, and Elizabeth Cady Stanton.

And, of course, Henry Nash Smith, who cites the Frenchman both as a gesture of affiliation, and to signal his critical relationship to it. Like Crèvecoeur, like Jefferson, like Whitman, and all the other cultural critics Smith discusses, and like, significantly, the anonymous authors and readers of dime novels, Smith commits himself to articulating a cultural vision of American democracy. To do so, however, requires casting a coldly critical eye on previous efforts. By tying the flourishing of individual freedom and

\footnotetext{
${ }^{44}$ Denning, "'Special American Conditions," 360, makes this point. Wise, "“Paradigm Dramas,", 307, puts it as an effort "to probe for the fundamental meaning of America."
} 
collective democracy to material conditions like westward expansion that have long vanished, Smith argues that nineteenth-century culturalists risked foreclosing the possibilities of "America" with the closing of the frontier. Smith's book, on the other hand, keeps alive a democratic commitment by in effect substituting for the "West" a critical cultural history of "the West" as the resource for national imagining. Or, to adopt Warren Susman's phrase, he, along with Lewis and Marx, sought to make the past "usable" to the present by affiliating his efforts with those of the figures they all studied in order to establish a canon of inquiry into the meaning of America that extended through more recent figures like Waldo Frank, Van Wyck Brooks, and Lewis Mumford. ${ }^{45}$

Of course Smith's critical thrust must be measured against its place in what Leo Marx describes as the era's "essentially holistic, affirmative, nationalistic project primarily aimed at identifying and documenting the distinctive features of the culture and society chiefly created by white European settlers in the territory now constituting the United States." 46 To reread many of the "American Mind" classics of the era-and for that matter, many of the consensus school histories - is to recognize how blind even the most sophisticated quest for cultural totality was to historical diversity and conflict, and how broadly it presumed a national hegemony formed around consumerism, family values, and corporate orthodoxy. This complicity with the culture of Cold War conservatism accompanied a vigorous institutional expansion of American studies, underwritten by the kind of substantial foundation grants and institutional support for research and curriculum development that would lead it from the shadows of Grub Street

\footnotetext{
${ }^{45}$ Warren Susman, "History and the American Intellectual: The Uses of a Usable Past," in Culture as History: The Transformation of American Society in the Twentieth Century (New York, 1984), 7-26.

${ }^{46}$ Marx, "Recovering the 'Ur' Theory," 121.
} 
and entrench it in elite universities and make possible a national convention and the American Quarterly. ${ }^{47}$ When in 1950 Yale received a substantial private endowment to begin its own American studies program, university president Charles Seymour argued that the "best safeguard against totalitarian developments in our society is an understanding of our own cultural heritage and an affirmative belief in the validity of our institutions of freedom, enterprise and individual liberty." 48

It was in part recognition of this complicity, made visible by over a decade of political and social turmoil, that made so wrenching the generational, intellectual, and political confrontations of Marx's "Great Divide" of the 1960s. ${ }^{49}$ If during the 1950s, American studies seemed best suited to prepare Richard Nixon to celebrate the democratic promise of consumerism in his kitchen debate with Khrushchev in 1959, by 1967 Robert Sklar would argue at one of the earliest regional ASA meetings, as the title to his paper put it, for practicing "American Studies as a Form of Dissent." ${ }^{50}$ It is tempting to see Sklar's direct equation of scholarship and teaching with political action (recall Lauter's “doing American studies is a political act”) as marking a paradigm shift away from the more measured formal discourse of Cold War era culturalists and towards the purge mentality that Wolfe sees in current American studies. But if we are to take Wolfe and Marx at their words about the deep tradition of dissent and adversarial culture at the heart of even Cold War scholarship, then critique - even when levied against the

\footnotetext{
${ }^{47}$ See Wise, “"Paradigm Dramas,"” 308-10.

${ }^{48}$ Davis, "Politics of American Studies," 355. Sigmund Diamond, "Lux, Veritas, et Pecunia," Prospects: An Annual of American Cultural Studies 16 (1991): 41-55; and Diamond, "Compromising American Studies Programs and Survey Research," International Journal of Politics, Culture and Society 6 (March,1993): 409-15.

${ }^{49}$ Marx, "Recovering the 'Ur' Theory" 123, $24,28$.

${ }^{50}$ See Davis, "Politics of American Studies," 359.
} 
luminaries of the past—emerges as that necessary practice which produces not only vigorous scholarship, but a vigorous culture. It is from this perspective that Donald Pease and Robyn Wiegman's collection of essays, The Futures of American Studies — the text that Wolfe most excoriates as "anti-American" - establishes a critical relationship to the past in order to imagine open-ended futures not just for cultural critique, but for vibrant cultures. ${ }^{51}$

That said, I do not want to overstate the continuities of a history that virtually all of the commentators I have cited characterize as marked by fundamental change. Patrick Brantlinger has coined the word "culturalization" to describe the increasing emphasis on meaning and relativity in the disciplines of humanity (anthropology, history, sociology) that challenges the integrity of our knowledge about the past. ${ }^{52}$ Over the past several decades this uncertainty has often been attributed to the irresponsible importation, or invasion, of foreign methodologies, vocabularies, and research agendas — classed loosely under the rubric "theory" - into the American academic body. This at least was how, in 1991 Stephen Watts characterized what he called "The Idiocy of American Studies." Arguing from the standpoint of "a kind of indigenous midwestern radicalism," (627) Watts voiced his impatience with the "discourse radicalism" of the "linguistic Left" (655) " $[\mathrm{m}]$ arching steadily, and often frolicking playfully, under the banners of French intellectuals such as Jacques Derrida and Michel Foucault," fomenting "a theoretically radical reading of American values and commitments that subverts, reverses, and generally tramples much of the American Studies tradition.” (626)

\footnotetext{
${ }^{51}$ Donald E. Pease and Robyn Wiegman, eds., The Futures of American Studies (Durham, NC, 2002).

${ }^{52}$ Patrick Brantlinger, "A Response to Beyond the Cultural Turn," American Historical Review 107 (Dec. 2002): 1500-12.
} 
On one hand, Watts's xenophobic language neatly captures the rhetoric of distrust that often stigmatizes poststructural incursions into "real" history as irresponsible, narcissistic, and finally, alien in language and disposition. On the other hand, Watts's is not a strict nativism. He objected to the Linguistic Left on two grounds. First, he felt that many of its practitioners substituted an easily obtained "discourse radicalism"celebrating the subversion of texts - for an engaged on-the-ground politics that would take comfortable academics out of their offices and into the community. Second, he criticized the "wildly fluctuating, almost incoherent picture of 'power' and human agency" shared particularly by scholars working in literary and art historical studies. It was one thing, he argued, to insist on the aesthetic value of sentimentalism, as did Jane Tompkins in her groundbreaking book, but it is quite another to do so with no attention to how it reinforced the gender-stratified, class-bound culture it celebrated. Such disjunction comes from isolating cultural critique of the past from its historical location. ${ }^{53}$

In a brief ending, Watts offers as an antidote to such "idiocy" the work of two other foreigners (neither of whom is French): Antonio Gramsci and Raymond Williams. They ground their work, he asserts, on culture and power more firmly in the soil of material life and history than do to the French discoursers. As such, without explicitly saying so, Watts gestures towards that body of work which has had the most profound impact on American studies in the last two decades: British cultural studies. Williams, at Cambridge University, along with such figures as Richard Hoggart, Stuart Hall, Richard

\footnotetext{
${ }^{53}$ Steven Watts, "The Idiocy of American Studies: Poststructuralism, Language, and Politics in the Age of Self-Fulfillment," American Quarterly 43 (Dec. 1991). 626 (quote 3), 627 (quote 1), 645 (quote 4), 655 (quote 2). Watts engages in particular with Richard Brodhead, "Sparing the Rod: Discipline and Fiction in Antebellum America," Representations 21 (Winter 1988): 69-72,, Jane Tompkins, Sensational Designs: The Cultural Work of American Fiction, 1790-1860 (New York, 1985), and Bryan Jay Wolf, Romantic ReVision: Culture and Consciousness in Nineteenth-Century American Painting and Literature (Chicago, 1982)
} 
Johnson at the Centre for Contemporary Cultural Studies, and others like E. P.

Thompson, made the relationship of power and culture the center of their inquiries into history and society. Key to their thinking about these issues were writers from the Frankfurt School (Theodor Adorno, Walter Benjamin), Louis Althusser, V. R. Volosinov, and Gramsci, all of whom were introduced to American readers, along with Foucault and Derrida, during the 1970s and 1980s. Together their writings have offered American culturalists a conceptual vocabulary for breaking down the oppositions of material base and superstructural ideas that plagued not only the Marxist tradition, but most studies of history and culture. Williams's concept of "cultural materialism"—in which he reconceives culture as a mode of production in its own right—particularly influenced U.S. scholars to link individual and collective "consciousness" (or "mind") to agency and experience. ${ }^{54}$ Key examples of this influence is marked by Trachtenberg's adoption of Raymond Williams's concept of incorporation to organize his interpretation of Gilded Age culture, and T. J. Jackson Lears's Americanization of Gramsci’s “hegemony” in his work. $^{55}$

Cultural studies has been particularly influential in provoking a more complex engagement by American culturalists with mass and popular cultures. Scholars in American studies have long valued the "higher arts" of literature and painting for the complexity of their insights into the dynamics of culture, while approaching popular and mass culture as either directly reflecting popular attitudes or, following the Frankfurt

\footnotetext{
${ }^{54}$ See Raymond Williams, Culture and Materialism (New York, 2005).

${ }^{55}$ T. J. Jackson Lears, "The Concept of Cultural Hegemony..” Another key moment is Richard Slotkin's revision of his use of "myth" in light of poststructuralism. See "Myth and the Production of History" in Ideology and Classic American Literature, ed. Sacvan Bercovitch and Myra Jehlen (New York, 1988): 70-90.
} 
School, as modes for the manipulation of audiences for the ends of commodity culture or state orthodoxy. Cultural studies has enabled us to see culture-_high" or "low," canonical or alternative-more fully in all of its contradictory complexity. Baseball, Moby Dick, or rock music simultaneously help produce often oppressive social orders (patriarchy, racial hierarchy, consumer culture), even as they offer sites of, or resources for, political subversion and resistance, and allow the imagining of alternate realities and futures. ${ }^{56} \mathrm{We}$ have as well come to re-conceive audiences and consumers as historical agents capable of resisting the encroachments of "official" cultures, and even to use products to their own ends, and to look to local, material, and performative cultures for alternative and anti-hegemonic expressions. ${ }^{57}$ Such approaches have yielded particularly rich results in the study of minority, or subaltern cultures.

The fit between cultural and American studies, however, has not been altogether seamless. British cultural studies, after all, grew out of the need to formulate a socialist politics in a postwar era when working class consciousness was in danger of being coopted by an increasingly Americanized mass culture. ${ }^{58}$ The transatlantic import of such a forthright activism has been problematic. As Denning has argued, the most powerfully direct impact of such politics in the United States came in the historiography of E.P. Thompson, Eric Hobsbawm, and Christopher Hill, whose pragmatic materialism and engagement with the working class inspired U.S. social and labor historians like Eugene

\footnotetext{
${ }^{56}$ The classic explications of these ideas remain Frederic Jameson, "Reification and Utopia in Mass Culture," Social Text 1 (Winter 1979): 130-48; and Hall, "Notes on Deconstructing the Popular."

${ }^{57}$ For an example of an American studies approach to this, see especially George Lipsitz, Time Passages: Collective Memory and American Popular Culture (Minneapolis, 1990).

${ }^{58}$ On the transnationality of cultural studies, see Joel Pfister, Critique for What? Cultural Studies, American Studies, Left Studies (Boulder, CO, 2006), 49-57. Richard Johnson "What is Cultural Studies Anyway?" Social Text 16 (Winter, 1986/87): 38-80.
} 
Genovese and David Montgomery. ${ }^{59}$ American culturalists, on the other hand-historians and studies scholars alike — still wrestling with the paradigm of exceptionalism (witness Watts's contrast of his "authentic" politics with French imports) have long engaged Marxist cultural theory with deep ambivalence. With the move of American studies from the shadows of "Grub Street" into the academy in the 1950s, and more broadly in the 1980s, the gritty activism of American cultural studies succumbed at least in part to a powerful professionalization. By the 1990s cultural studies in the United States (including history and American studies) was regarded abroad as a "ccautionary example' of how cultural criticism can be institutionalized and co-opted by the bourgeois US academy. ${ }^{60}$ It is under these conditions that the vigorous language of cultural engagement tends at times towards the recondite jargon of "cult crit." The strident, almost militaristic (texts are "interrogated," essays are "interventions," etc.) rhetoric of its political urgency that can characterize the most considered culturalist scholarship, can isolate intellectual work from broader audiences and hence greater influence - this despite the genuine political efforts of many Americanists in their teaching, research, and non-professional lives. ${ }^{61}$ At worst, such language can function as form of intellectual "branding" in an academic environment of competitive individualism, as Winfried Fluck

\footnotetext{
${ }^{59}$ Denning, "“Special American Conditions,” 357.

${ }^{60}$ Pfister, "Americanization of Cultural Studies," 209.

${ }^{61}$ Patricia Limerick has had "plenty of occasions to feel impatient with and worried about the disadvantages of the jargon and complacency of quite a number of applications of cultural theory. When I think about the really quite substantial effort that one must go to, to 'translate' scholarly work to wider audiences (and smart audiences at that), I wonder why so much effort must go into creating the initial obscurity that then occasions the need for translation." In Drew Faust, Hendrik Hartog, David A. Hollinger, Akira Iriye, Patricia Nelson Limerick, Nell Irvin Painter, David Roediger, Mary Ryan, Alan Taylor, "Interchange: The Practice of History," Journal of American History 90 (Sept. 2003): 588.
} 
as argued, or simply as the product of an escalating jargon race for the professional prize of erudition status, as Robert Frank has suggested. ${ }^{62}$

Nonetheless, American studies sustains a very productive dialog with cultural studies not only because of mutual interests in power and culture, consciousness and agency, but was well because of an openness to a dialectic between theoretical and historical knowledge. Nor is this commonality a new phenomenon; Joel Pfister has described how a transatlantic dialog with American leftists helped shaped the early thinking of Stuart Hall and Richard Johnson on politics and culture. ${ }^{63}$ Given this complementarity, it is not surprising that American studies is vulnerable to the same critique as cultural studies, which, in its emphasis on current politics, has found difficulty in integrating history into its formations of cultural power. For instance, were citizens living before the onset of mass cultures of media and consumerism subjected to the same dynamics of cultural power as those today? How accurate is hegemony - the manufactured consent of the governed-in describing the cultural politics of the early nineteenth century? The answers to these questions can only come not only from investigating the past, but as well from historicizing the ascendancy of culturalism as the dominant mode of inquiry. In other words, there is still more work ahead for "cult crit."

\footnotetext{
${ }^{62}$ Pfister, "Americanization of Cultural Studies," 223. Robert Frank, The Economic Naturalist: In Search of Explanations for Everyday Enigmas (New York, 2007), suggests one reason for the propensity of humanities scholars for jargon: an escalating competition for the display of erudition. Winfried Fluck suggests that a market-based academic culture of expressive individualism in the humanities encourages tenure- and status-seeking intellectuals to "brand" their work with a particular valence of criticism. See Fluck, "The Humanities in the Age of Expressive Individualism and Cultural Radicalism," in Pease and Weigman, Futures of American Studies, 211-30.

${ }^{63}$ Pfister, Critique For What?, 23-81.
} 
During the last decade the most persistent issue of cultural critique has challenged scholars of American studies, as well as American historians, to re-think their relationship to "America" on a number of fronts. First, the identity studies that so dominated scholarship in the 1990s, particularly those associated with race and ethnicity, worked to denaturalize national identity by emphasizing the migratory and contingent existence of modern peoples: Crèvecoeur's "what is an a American" evolved into "who makes whom an American, for what ends, and for whose benefit?" Of course, in a broad sense, Crèvecoeur's original question presumed a cultural dynamism implicit in the category of the national that anticipates today's culturalism. But some scholars have gone so far as to, in Donna Gabaccia's terms, to challenge "the tyranny of the national" altogether as a category for analysis ${ }^{64}$. Her work on Italian migrants living in a transnational space between, as it were, nations, complements that by Lisa Lowe on migrant laborers and James Clifford's formulation of "traveling culture." 65 Such scholarship has joined "border studies" that focus particularly on the relationship between the United States and Latin America to emphasize the hybridity and creolization of culture and identity, and to challenge at the conceptual level the legitimacy of national borders between outside and insiders. ${ }^{66}$ These challenges to the "national" have

\footnotetext{
${ }^{64}$ Donna R. Gabaccia, "Is Everywhere Nowhere? Nomads, Nations, and the Immigrant Paradigm of United States History," Journal of American History 86 (Dec. 1999): 1115. Her article appears in a special issue, "The Nation and Beyond: Transnational Perspectives on United States History."

${ }^{65}$ Lisa Lowe, Immigrant Acts: On Asian-American Cultural Politics (Durham, 1996); James Clifford, The Predicament of Culture: Twentieth-Century Ethnography, Literature, and Art (Cambridge, 1988) and Routes: Travel and Translation in the Late Twentieth Century (Cambridge, 1997).

${ }^{66}$ Milette Shamir raises this issue in "'Our Jerusalem': Americans in the Holy Land and Protestant Narratives of National Entitlement” American Quarterly 55 (March, 2003): 29-60.. For an
} 
complemented efforts to incorporate U.S. history into a broader history of imperialism, sparked by the compelling scholarship in postcolonial studies, the erosion of the exceptionalist paradigm of U.S. studies, and of course the emergence of the United States as the global superpower with a foreign policy committed to global intervention. Whatever "America" may stand for, whatever associations it may have with ideals of freedom and democracy, the United States has actively expanded its territorial borders, conquered peoples, and used military force and economic power in the name of national interests. Together, studies in transnationalism and imperialism have worked to unhinge the tight connection between "America" and the United States, even as they have linked the power of culture with that of the state. Such concerns have changed the questions and focus of virtually all academic fields focused on "American," but they have had a particularly powerful impact on American studies. For a field that takes as its ongoing concerns culture, power, and national identity, to question the borders of "America," is not only to challenge scholars to explore more critically the relationship between the nation-state and its cultures, but to question the logic of its own aspiration. What would “American studies" be without "America?"

Within American studies these issues were keynoted by two important essays in the 1990s. The first appeared as the introduction by Amy Kaplan to a well-known collection of writings she edited with Donald Pease, Cultures of United States Imperialism (1993). ${ }^{67}$ The second was first delivered by Janice Radway as the presidential address at the 1998 American Studies Association convention, and

overview of border studies in history, see Jeremy Adelman and Stephen Aron, "From Borderlands to Borders: Empires, Nation-States, and the Peoples in between in North American History," American Historical Review, 104 (June 1999): 814-41.

${ }^{67}$ Amy Kaplan and Donald Pease, eds., Cultures of United States Imperialism (Durham, 1993). 
subsequently published in American Quarterly in $1999 .{ }^{68}$ Both of them have been reprinted and widely cited as galvanizing calls to rethink the project of American studies; together they give a good idea of the current, more globally conscious, place of American studies today.

In her essay, "Left Alone with America," Kaplan builds her argument, in a simultaneous gesture of affiliation and critique, around an extended deconstruction of Perry Miller's evocative preface to Errand Into the Wilderness (1956). There, Miller tells of discovering his calling to expound "the meaning of America" ${ }^{69}$ while unloading drums of oil in the port of Matadi, in the Congo. Kaplan seizes on the paradox of that scholar most identified with the puritan-origins theory of America grasping his intellectual destiny perched, as Miller tells us, "on the edge of the jungle of Central Africa." ${ }^{, 70}$ What is it, she asks, about Africa that provokes one of the most persistent models of American exceptionalism? And why is the source of that provocation not included in that vision? The answer to the latter question is implied by that to the former. As one of the nodes in the triangle trade of slaves, raw material, and manufactured materials and as an important site for the formation and maintenance of twentieth-century European imperialism, Africa does not fit into Miller's national origin tale of heroic New England travail. Nor for that matter does the long history of the United States' investment in the global commerce of imperialism (which brought a young Miller to the Congo) fit well with presumptions of a distinct American culture that stops at the borders of the nation. Thus Kaplan urges scholars to in effect restore Africa to our understanding of America, to

\footnotetext{
${ }^{68}$ Janice Radway, "What's in a Name?: Presidential Address to the American Studies Association, 20 November 1998," American Quarterly 51 (Mar. 1999): 1-32.

${ }^{69}$ Quoted in Kaplan, "Introduction," Cultures, 6.

${ }^{70}$ Ibid.
} 
"reconnect" the United States to the rest of the world, and to reconstruct in global terms a cultural history that has too often been isolated from the politics of foreign relations. To this end, her collection focuses on "the multiple histories of continental and overseas expansion, conquest, conflict, and resistance which have shaped the cultures of the United States and the cultures of those it has dominated within and beyond its geopolitical boundaries." 71

Radway cites Kaplan and reiterates her point in order to raise a more sustained critique of the use of "American" in "American studies." She too turns our attention to previous scholarship, though in her case she turns from the standard figures of the "golden era" to a neglected tradition of critical scholarship that begins roughly with José Martí’s 1891 essay, "Nuestra America," and includes writers like W.E.B. Du Bois and C.L.R. James. Each of them, she points out, have mounted critiques of Western imperialism by associating "America" with the entire hemisphere, not just the United States, thus reimagining conquest and democratic struggle across national boundaries. In focusing on often mobile communities (racial, sexual, geographical, ethnic) that either are smaller, and yet relatively distinct from, hegemonic national cultures, or that exceed national borders altogether, their writing suggested the primacy of cultural identities that know no political boundaries. They instead are formed, altered, challenged, and reinforced across shifting social networks of "intricate interdependencies" that exceed national borders, moving globally through "multiple, shifting, imagined communities." 72 Not only, argues Radway, is a traditionally nationalist American studies unable to map such culture, it is complicit with the nation-state's attempts to colonize and domesticate

\footnotetext{
${ }^{71}$ Kaplan, "Introduction," Cultures, 4.

${ }^{72}$ Radway, "What's in a Name?," 10-15.
} 
such identities, thereby reproducing in scholarship the imperial arrogance inherent in the United States” claiming “America” for itself.

Early responses to the challenges outlined by Kaplan and Radway yielded vigorous growth in what Susan Gillman has characterized as an "empire studies" committed "repeatedly to discover and announce empire's presence, each time with the same shock of the new," each time asking the "astonishingly crude" question, are you for it or against it $?^{73}$ The assumption running through such work, as Sandra Gustafson has put it, was that democracy and imperialism were antithetical. ${ }^{74}$ Over the subsequent decade and a half, however, different questions, methods, and issues have emerged to meet the complexity of a United States formed and flourishing in a global history of imperial dominion. This is apparent in our sample of recent scholarship, in which more than a third of the articles in both American studies and American history dealt broadly with transnationalist or imperialist issues. ${ }^{75}$ In American studies, questions are formulated in ways that both draw on, by challenging, traditional American studies interests in culture, even as they respond to the globally sophisticated vision of cultural studies and charges of parochialism levied by Americanists outside of the United States. At the same time, by critically opening out what was until the 1990s the under-theorized term of "nation," this new vein of inquiry extends questions of identity in new directions. ${ }^{76}$

\footnotetext{
${ }^{73}$ Susan Gillman, "The New, Newest Thing: Have American Studies Gone Imperial?" American Literary History 17 (Spring 2005): 196-98. .

${ }^{74}$ Sandra M. Gustafson, "Histories of Democracy and Empire," American Quarterly 59 (Mar. 2007): 117.

${ }^{75}$ Eight out of twenty-three articles in $A Q$ and seven out of eighteen in the history journals can be construed as engaging the topic.

${ }^{76}$ This describes the logic behind Pease and Wiegman, The Futures of American Studies. A recent engagement with these issues animates Caroline Levander and Robert S. Levine, eds., Hemispheric American Studies (New Brunswick, NJ, 2008).
} 
These possibilities are particularly apparent in Kaplan's more recent book, The Anarchy of Empire, and in Laura Wexler's Tender Violence. What distinguishes their work from earlier dualistic approaches is their shared contention that, for more than a century and a half, and most particularly during the late decades of the nineteenth and early decades of the twentieth centuries, the politics of empire not only shaped American democracy, they had a hand in making us who we are as citizens, as men and women, as inhabitants of a national culture. Together they are less interested in the "front lines" of imperialism - the violence and social upheaval of colonial encounter — than they are in the cultural seepage, if you will, of this conquest into the most intimate subjectivities of people often most privileged enough to avoid direct contact with it. Finally, judging by reviews, both books have provoked responses by historians that suggest that readily exemplify the difficulties of bringing together history and cultural critique. Both Shirley Wajda, writing thoughtfully in $J A H$, and Christoper Capozzola, writing in the Journal of the Gilded Age and Progressive Era, generally endorse Wexler's work as a reminder, in Capozzola's words, "for historians...to theorize more explicitly and argue more coherently about the relationship between power and culture," even if her own claims to photography's power to shape agency are "extravagant." 77 The numerous reviews of Kaplan's work acknowledge both her wide influence and how her writing speaks to present day politics. ${ }^{78}$ At the same time, historians also question her claims for the power

\footnotetext{
${ }^{77}$ Shirley Teresa Wajda, review of Laura Wexler, Tender Violence: Domestic Visions in an Age of U.S. Imperialism, Journal of American History 89 (Dec. 2002): 1078-79. Christopher Capozzola, "Empire as a Way of Life: Gender, Culture, and Power in New Histories of U.S. Imperialism," Journal of the Gilded Age and Progressive Era 1 (Oct. 2002): 370-71.

${ }^{78} \mathrm{~A}$ good gauge of Kaplan's influence comes in a review of a collection of essays on North American empire in which Jon Smith wonders, "Has American studies stalled out, with the best boomers in the business still writing elaborate footnotes to Amy Kaplan?" Jon Smith, review of
} 
of the culture she studies. Writing in $J A H$, Dolores Janiewski particularly objects to Kaplan's tendency "to conflate metaphor and power relations in a way alarming to historical sensibilities." ${ }^{, 79}$ As such these books both exemplify scholarship in the field "in our time," and mark the fault line between American studies and history.

Laura Wexler's book appeared in 2000 as the culmination of over a decade of provocative articles on sentiment, domesticity, and photography. Indeed, as she puts it in her book, her study began as an exploration of women photographers. Her earliest article included in the book focused on, among others, Frances Benjamin Johnston's luminous photographs of the Hampton Institute in $1899 .{ }^{80}$ Two years later she returned to Hampton with a more focused eye in an article that coined the phrase that titles her book. ${ }^{81}$ At this point she engaged with sentimentality and domesticity less as discourses of femininity and more as modes of caring, or "tender" discipline. ${ }^{82}$ And yet, for all the historical specificity of her subject matter, her interests are frankly theoretical: Hampton was a disciplinary institution akin to the prisons described by Michel Foucault; at stake for her was how photography, and in particular photography by women, participated in the harsh

\footnotetext{
Ann Laura Stoler, ed., Haunted by Empire: Geographies of Intimacy in North American History, Journal of American History 93 (Mar. 2007): 1273.

${ }^{79}$ Dolores Janiewski, review of Amy Kaplan, The Anarchy of Empire in the Making of U.S. Culture, Journal of American History 90 (Mar. 2004): 1488. See also Anders Stephanson, "Imperial Pursuits," Diplomatic History 28 (Sept. 2004): 581-86; and Nikhil Pal Singh, "The Spectacle of Empire," American Quarterly 56 (June 2004): 429-37.

${ }^{80}$ Laura Wexler, "Black and White and Color: American Photography at the Turn of the Century," Prospects: An Annual of American Cultural Studies 13 (1988): 341-90.

${ }^{81}$ Laura Wexler, "Tender Violence: Literary Eavesdropping, Domestic Fiction, and Educational Reform," Yale Journal of Criticism 18 (Fall 2005): 355-70. Repr. in Shirley Samuels, ed., The Culture of Sentiment: Race, Gender and Sentimentality in Nineteenth Century America (New York, 1992), 9-38.

${ }^{82}$ Richard Brodhead was among the first to explore these issues. See his "Sparing the Rod: Discipline and Fiction in Antebellum America," Representations 21 (Winter 1988): 67-96.
} 
transformation — all in the name of a family-like concern — of Native and African Americans into productive and politically quiescent citizens. ${ }^{83}$

This theoretical emphasis on the power of culture remains very important in her book. As she states in her introduction, Wexler wants to challenge the aura of transparent truth-value attributed to still photography by recovering the uses both the act of photography and the circulation of photographs were put to. To do this, she proposes to read photographs, and indeed all historical evidence, "against the grain," against whatever apparent intentions may have prompted their making, and whatever meanings they may have had for those who viewed them (8). ${ }^{84}$ Thus family photographs, as well as more aesthetically ambitious images by the likes of Johnston and Gertrude Käsebierpictures that dramatize relations of affection and intimacy—need critical deconstruction and reinterpretation as forms of representation that exclude as dynamically as they include. Paradoxically, she posits that the "meaning" of an image (and, it seems to me, a document or object) lies as persuasively in what is not visible, as in what is there. Thus Wexler's questions offer necessarily incomplete answers at times based on more speculation than many of us might be comfortable with.

That said, however, she formulates her queries out of a rigorous use of archival material - mainly, but not exclusively, photographs — and a broad mastery of secondary material on the period. Historically, I find most compelling her largely successful effort to extend the history of sentimentality beyond the Civil War by documenting its efflorescence outside the middle-class home and the literature on family and slavery. In

\footnotetext{
${ }^{83}$ See Michel Foucault, Discipline and Punish: The Birth of the Prison, trans. WHO? (New York, 1975).

${ }^{84}$ Wexler borrows the phrase from Alan Sekula, Photography Against the Grain: Essays and Photo Works, 1975-1983 (Halifax, Nova Scotia, 1984).
} 
her hands, sentimentality emerges as remarkably adaptable, shaping the ends and means of institutions of reform and education and offering a visual frame for white middle-class Americans to negotiate and legitimate — to domesticate —often uneasy, at times violent encounters with people unlike themselves. In short, it emerges as the discourse for humane concern. In the end, though, Wexler writes very much as a historical revisionist. Her object is less to narrate or explain historical change - this book works best neither as a history of sentimentality nor of women photographers - than it is, again borrowing from Foucault, to construct a "counter-memory," i.e. a critical way of challenging the commonplaces of the past that make the present seem inevitable. Thus her book is best taken as provoking readers to think differently as much about the present as about the past: "The narratives we make about domestic photographs, relating image to image and to other cultural forms, have helped to shape our current violent predicaments of race, class, and gender" (299).

This reflexive attention to method and history makes for a particularly selfconscious and complex book. While she keeps women and gender as a central issue throughout, each chapter develops a different theoretical issue to frame its historical focus: domesticity and imperialism; sentimental photography and slavery; the use of images to "discipline" the transformation of Indians and African Americans into proper citizens; the relationship of domestic intimacy and urban street life; worlds fairs and the display of racial hierarchy. Wexler makes little effort to link one chapter to another; the photographers she writes about have little or no contact with one another. What does unite her book is her rigorous and expansive attention to what she calls "the averted gaze," a culturally constructed mode of not seeing. 
Wexler's book opens by examining Johnston's frankly charming images of life aboard Admiral George Dewey’s flagship taken in 1899, one year after he had vanquished the Spanish fleet in Manila Bay in the Philippines. Against a backdrop of disturbing accounts of hometown white American boys torturing and killing Filipinos, Johnston's beautifully composed images of domestic shipboard life, complete with laundered uniforms and languid poses, give sentimental images of military men as "home boys," or even "mamma's boys," who could never be "arsonists, rapist, looters, lynchers" (35). As such, Johnston and Dewey forge a bargain to unite white bourgeois men and women against a common uncivilized foe. The second chapter moves back in time to explore a number of domestic photographs of black servants and white family taken at mid-century by the Cooks, a wealthy slave-holding family in Richmond, Virginia. On many levels, this choice is arbitrary: the Cooks had little or nothing to do with Johnston, Dewey, or the Philippines; it is highly unlikely that Johnston saw any of the family images Wexler discusses. ${ }^{85}$ For Wexler, however, these disjunctions are irrelevant; the Cook images serve as a kind of prequel to Johnston's work. In composing for instance, a Madonna-like picture of a black "nursemaid with her [white] charge," Cook laundered fraught racial tensions as domestic tranquility. As such, his images exemplify how Americans "coded...domesticity as a benign or even a benevolent force," which enabled "a compromise with or even a flirtation with the mechanics of racialized terror that kept a firm hold throughout the entire course of the nineteenth century"(53), and which framed the theatrical domesticity of Johnston's images.

\footnotetext{
${ }^{85}$ Both father and son were professional photographers; the former known for his images of Confederate and Union officers during the war, the latter an early "field" photographer who made many of his images outside the studio.
} 
Needless to say Wexler's contentions about the meanings of photographs depends heavily on the sophistication of her use of historical context. Thus it is worth considering more deeply her analysis of the nursemaid picture, which comprises the centerpiece of this second chapter. Her goal is to reconstruct the conditions of its making and use in all their complexities, and thus to "restore a certain degree of voice and context" to those photographic subjects who remain silent in history (57). To do so, however, poses many challenges, each of which she discusses in detail. She knows neither the name of the nursemaid, nor the exact date the image was taken (1865 or 1868). Thus she cannot offer a narrative of precisely how or why the picture came to be taken or why it was preserved (was it a "baby picture"? a portrait of the nursemaid? simply an exercise in lighting? was the woman a slave or servant?). The image's significance, however, is not embedded strictly in its content; rather its meaning emerges "as a system of relations that are established not in but between images" (66; emphasis in original). Thus, by triangulating between the detail and form in the image, the discourses and traditions of art history and sentimentality, and the historical circumstances of the Cook family and race relations in Richmond, Virginia during and just after slavery, Wexler offers a compelling reading of the image, or rather of the cultural habits that made the clearly painful relations between races seem to be the appropriate subject for an apparently irony-free picture of family intimacy.

Such an interpretation invites us to see the image as a complex meeting of invisibility and visibility. Or, to put the matter in more historical terms, Wexler presents the photograph that, for all of its apparent realism, produces a mode of seeing that blinds viewers past and present to the violence inherent in racial inequality for the sake of being 
charmed by the sentiment of domestic intimacy. In fact the historical and critical consequences of this "averted gaze" could be taken as the subject of her book. In the following chapter she argues that the conventional "before" and "after" pictures of Native American students at the Hampton Institute - first dressed in the customary clothing of their home life, and later, after months of training, dressed as "imitation white girls," complete with hair bows and dolls (112) — represented as miraculous and benign a process experienced as both physically and psychologically violent. In the following chapter she returns to Johnston, who, on the basis of her work with Dewey, was hired by Hampton to produce images for publicizing its mission of uplift. Wexler examines how the hauntingly beautiful, even elegiac photographs of her images of students in the classroom fence off the fierce debates over race and war that surrounded the institute. She follows this with chapters devoted to exploring the relationship between Gertrude Käsebier's pictures of white motherhood and her Indian portraits; the tensions between Alice Austen's quirkily theatrical domestic images and her street photography of New York City's recent immigrants, and Jesse Tarbox Beals's enthusiastic embrace of racial exoticism in her ethnographic images from the St. Louis World's Fair. Throughout, she remains intent on explicating the violence and intolerance that goes hand in glove with the tenderness of sentimental culture, and the blindness that allows them to co-exist.

Wexler's text stands squarely in the tradition of American studies scholarship. Her critique of what she sees as the public sphere's bad-faith engagement with the nation's history of racial violence, her insistence on seeing the past in dialog with the present, and her commitment to using specific examples of complex culture as exemplars of larger historical energies — all of this affiliates her with the likes of Smith, Marx, and 
Trachtenberg. ${ }^{86}$ At the same time, however, the "America" she writes about resembles more that of Radway than Henry Nash Smith's: national identity is shaped by the conflicts and hierarchies of difference that benefit some at the expense of many, not by the adhesion of common culture. Her aggressive interpretation, her eclectic use of critical theory, even at times her language, place her book in dialog with cultural studies and women's studies in particular. This makes for one of the very best books in the field, but it also makes for one that shares many of the limitations of cultural critique. As she is well aware, like all interpretation, Wexler's method of reading the visible in terms of the invisible, while provocative and sophisticated, is vulnerable to the critic's foibles of "ignorance and blindness that are cultural as well as personal" (57). "Case study" scholarship, particularly that which leaves implicit the connections and continuities between, say Johnston's images and those of the Cooks, has very little to say about how that culture was transmitted between historical actors. The vaguely structural assumptions Wexler employs suggest that culture is a kind of atmosphere, an air we breathe that is everywhere and nowhere, much like the myths and symbols analyzed by earlier scholars. But such critique is not to diminish Wexler for what she does not do, but to point to the necessary limitations that make so valuable the rich stimulus she offers her readers.

Amy Kaplan's book, The Anarchy of Empire, can best be understood as in close dialog with Wexler over much the same historical dynamic (they acknowledge and cite one another). Like Wexler's, Kaplan's book is comprised of revised articles written over the previous decade; thus it works in a similar "case-study" mode, though it is ordered with more attention to chronology. Kaplan also concerns herself less with the shock of

\footnotetext{
${ }^{86}$ Trachtenberg was Wexler's colleague at Yale, and edited the series for UNC Press in which Wexler's book appeared.
} 
acknowledging the reach of US imperialism than she does with how the culture of empire shaped the world we have inherited. And while she does spend more time on the front lines, or at least with accounts of conquest, she explores with equal attentiveness how imperialism shaped and was shaped by the gendered worlds of domesticity at home. In doing so, however, she discusses masculinity as well as femininity, which points to a close intellectual kinship with Kristin Hoganson, Gail Bederman, and Ann McClintock. ${ }^{87}$

If she does not concern herself precisely with the mechanisms of blindness as does Wexler, she still develops a sophisticated critique of the ideological obfuscations that justified a foreign policy bearing at best a questionable relationship to national commitments to equality and democracy. This is not so much a matter of the deliberate spin of politics, as it is a cultural process she memorably characterizes as "manifest domesticity." Kaplan coined the vastly influential phrase as the title of an article published in American Literature in 1998, which comprises in slightly modified form the second chapter of her book. ${ }^{88}$ It is indeed a catchy phrase. By deftly displacing "destiny" from John L. O’Sullivan's well-known invocation of the inexorable expansion of U.S. borders during the nineteenth century with the cognate "domesticity," Kaplan compactly dramatizes the larger argument of her article and indeed her book. From the time of the United States-Mexican War to the invasion of the Philippines (and later), the apparently antithetical cultures of middle-class domesticity and political empire shared "a vocabulary that turn[ed] imperial conquest into spiritual regeneration in order to efface

${ }^{87}$ Gail Bederman, Manliness and Civilization: A Cultural History of Gender and Race in the United States, 1880-1917 (Chicago, 1995); Kristin Hoganson, Fighting For American Manhood: How Gender Politics Provoked the Spanish-American and Philippine-American Wars (New Haven, 1998); and Anne McClintock, Imperial Leather: Race Gender and Sexuality in the Colonial Contest (New York, 1995).

${ }^{88}$ Amy Kaplan, “Manifest Domesticity,” American Literature, 70 (Sept. 1998): 581-606. 
internal conflict or external resistance in visions of geopolitical domination as global harmony" (31). America, it seemed to many, came not to conquer, but to make the world one big happy family.

Manifest domesticity, however, was not just a cover for empire; empire offered as well a compelling vision for domestic destiny. What does it mean, Kaplan asks, when domestic writers like Catherine Beecher, in her Treatise on Domestic Economy, envision the "mother and housekeeper" as a plain-style Queen Victoria overseeing as sprawling and as important an empire as that of England? To be sure, such hyperbolic paeans to the "empire at home" (quoted in Kaplan, 28) served to rhetorically compensate women for their limited access to what Susan Warner called as the title of her bestselling novel of 1850, “The Wide Wide World” of masculine action. But such language also suggests the extent to which "mothering" children at home was imbued with the same aura of civilizing as was colonizing races lower on the ladder of civilization in Mexico, Cuba, and elsewhere. Concurrently, when figures like O'Sullivan and, later, Theodore Roosevelt, imagined empire in domestic terms, at times justifying invasion of other countries to protect women and children (both within and without the borders of the US), it is clear that, despite the boundaries of private and public, masculine and feminine, domestic and foreign, domestic rhetoric "became the engine of national expansion, the site from which the nation reaches beyond itself through the emanation of women's moral influence" (29). Nor was such rhetoric limited to expressing fantasies of dominion. Female outreach may have been the paradigm for "civiliz[ing] the foreign" (a large factor, say, in the ideology of settlement homes), but it also gave voice to anxieties about bringing "foreignness into the home," whether that be defined by the comedy and travails 
of "barbaric" children in the family, unease over the influence of (often foreign-born) domestic servants, or the more disconcerting influx of unruly, "childish" inhabitants of conquered territories, and immigrants from uncivilized nations.

Throughout the book Kaplan explores the complex reverberations of the "imperial logic" that brings together even as it hides the connection between the foreign and the domestic in fiction, film, advice literature, political oratory, and the like. Her second chapter explores how Mark Twain's encounter with the "imperial violence" of the plantation sugar economy in the Sandwich Islands, written about in Roughing It, provoked in him "uncanny echoes" of "the ongoing violence of slavery" that persisted past emancipation, and which led him to his personal, and the nation's racial heart of darkness in his major fiction (75). Huckleberry Finn as well as Connecticut Yankee thus should be understood as in dialog with imperial writers like Rudyard Kipling and Henry Stanley "about the incapacity of nonwhite people to govern themselves, and the power of international capitalism to transform them into a modern labor force" (90). Several of her chapters explore the ways in which white male bodies came to stand in for a whole, virile nation. Thus the spate of popular historical romances by the likes of Richard Harding Davis written in the late years of the nineteenth century configure foreign conquest as chivalric rescue, thereby offering ways to imagine an American manhood revitalized after suffering "from the threatening forces of industrialization and feminization at home" (9293). Key to this manly re-charging are Anglo women characters free of the domestic sphere and engaged in the wide world of adventure, who are subsequently re-feminized as grateful objects for rescue and admiring witnesses to the robust fortitude of American heroes. In another chapter, Kaplan juxtaposes numerous accounts of the Battle of San 
Juan Hill, in which the Roughriders made their mark on the public imagination, in order to highlight a systematic exclusion of African Americans and native Cubans, both of whom played vital roles in the fight. In effect, accounts by Roosevelt, Stephen Crane, and others sought to claim chivalry, and hence true nationhood, as a privilege of whiteness. Her final two chapters take a more retrospective approach as they engage with the cultural half life of fin-de-siècle imperialism. One traces the persistent, if submerged presence of the Spanish-American War in American cinema, focusing especially on Birth of a Nation and Citizen Kane, case studies of how narrative film's "capacity to tell stories arose as much from a political desire to project national narratives of imperial conquest and geographic mobility as from technological or aesthetic innovation" (153). The final chapter develops an extended reading of W. E. B. Du Bois' novel Darkwater (1920) as an example of his profoundly internationalist understanding of how slavery and American racism were linked to colonialism. Like that of Twain's, his writing "both charted and was embedded in the transnational routes and networks of imperial power" it sought to represent (174).

Such a summary makes clear that Kaplan's is a much more literary enterprise than Wexler's, despite their shared emphasis on interpretation. While both writers approach culture in decidedly discursive terms - culture represents those activities which make life meaningful to those who make it - they do so from different points of entry. Wexler works primarily out of Foucault, exploring the links between power and knowledge, rediscovering "the ruptural effects of conflict and struggle" on the largely smooth face of "the order of things," the common sense that orders social knowledge (56). ${ }^{89}$ Kaplan's

\footnotetext{
${ }^{89}$ The Order of Things (New York, 1970) is the title of Foucault's most influential book.
} 
concern with narrative devolves from what could be called a "classical" deconstructionist approach. Because all meaning is contingent, because what we understand "here" to mean depends on what "there" is (and of course everything in between), the ways in which opposing or antithetical categories are constructed reveal much about how we organize the world which these terms are supposed to represent. Thus the elegance of her compact highlighting of the codependency of foreign and domestic in "manifest domesticity."

A useful example of Kaplan's deconstruction of historical texts comes in her introduction, where she focuses on a Supreme Court case of 1901, Downes v. Bidwell, over whether import duties should be imposed on a crate of oranges that arrived at the Port of Boston from the newly acquired possession of Puerto Rico. The court's decision that such duties were allowable hinged on a remarkably convoluted assessment of Puerto Rico's status as part of the United States, which Kaplan sees as exemplary of the nation's difficulties in reconciling an acquisitive imperialism with republican values. Chief Justice Edward Douglas White "resolved" the case with a marvelously ambiguous phrase that Kaplan seizes upon: Puerto Rico was a possession, not a state, so it was "foreign . . . in a domestic sense" (2). The only way to make sense of such contradictory language, argues Kaplan, is to understand the two terms not as verifiable categories of fact "but heavily weighted metaphors imbued with the racialized and gendered associations of home and family, outsiders and insiders, subjects and citizens" (3). In other words, the rational deliberations of the highest court in the land are shaped by a language so slippery, so shot through with contradiction, that even the driest of decisions - to tax or not to taxremained linked to a chain of associations that bound the foreign to the domestic. In this 
rhetorical interdependency lies the work of culture. Thus for instance, while there is no legal connection between Downes v. Bidwell, and the 1831 decision declaring Cherokees, and thus all Indians, members of "domestic dependent nations," the way in which "the language resonates" between the two cases makes historically clear how important establishing racial distinctions between (white) citizens and (non-white) others, both foreign and domestic, was to the Court's articulation of national borders and the formation of national identity (10). Distinctions between words legitimated and created differences between peoples.

The formation of boundaries, political, legal, linguistic, social, have long had a place in the study of nationalism, particularly in the flourishing work of border studies. However, in deconstructing the language of the cultural center, Kaplan in effect traces the conflict and hybridity of the border to the capital. Her object is to explicate "the work of imagining," the attempt, in the face of apparent metaphorical and political anarchy, to draw boundaries - between words and meaning, between peoples, between categories, and of course between nations and territories - that lies at the heart of "legitimating the project of American imperialism" (11). By following the language in sources, teasing out the paths of meaning meshed into public discourse, she is able set in motion the processes whereby American culture made itself. If Wexler emphasizes the signs of struggle and resistance to the power/knowledge matrix of official culture, Kaplan critically evaluates the labor of constructing such a hegemony.

Kaplan's book shares many of the limitations of Wexler's, and indeed with those of the field as a whole. Her argument can best be seen as focusing on the symptoms of imperialism, which her essays map as it metastasizes in the body politic. Her focus stays 
close to the nation's cultural center: Stowe, Twain, Roosevelt, D. W. Griffith, even Du Bois all participated, for all their critical energy, in an expanding and vigorous popular culture. And yet, there remains the question of just how that culture functioned, what exactly it represented about the people who lived in and created it. Finally, like Wexler, Kaplan offers her work as a form of historical revision. "My essays," she writes, "do not aspire to provide historical coverage, a new periodization, or a developmental narrative." Rather, she challenges the historiographic tendency to separate "continental expansion and overseas empire" and "territorial annexation to deterritorialized forms of global domination" (17). Like a good deconstructionist, she sees such conceptual boundaries as key to maintaining an aura of national exceptionalism akin to that voiced by Frederick Jackson Turner and Perry Miller. Equally importantly, they also obscure the persistent continuities of empire in the nation's history and hence the centrality of imperial ambition to the formation of American culture. Thus like Wexler, and like the best work in American studies, her goal is to stimulate exactly that historical re-thinking that they do not pursue.

Reviewers of both books comment on how each provokes historians to think more theoretically. Certainly, given their limitations and strengths, they challenge all scholars to think more explicitly (to theorize) about how culture works: when, what, and how it causes and prevents, authorizes and forecloses, produces and destroys people's efforts to live how they want. But I would like to make a friendly amendment to the call to theory. As a word, "theory" suggests a "foreign" discourse, a jargon, a form of thinking imported to history, just one tool, and a particularly unwieldy one at that, in the historian's toolbox, 
that can be picked up and put down as needed. More to the point, "theory" is really inadequate to what either scholar intends or accomplishes. For all of its deconstruction, Kaplan's writing is notable less for its theoretical sophistication than for the elegance with which it integrates her readings of specific language into a forceful argument about the significance of that example. It is this simplicity, I would hazard, that has made her work so widely influential. However, it also makes her work less useful to scholars and critics less interested in the culture of empire. Too often her interpretations of novels (this is particularly the case for those by Davis) unfold as allegories in lock-step with larger historical narratives of imperial expansion that are presumed rather than argued. Theory is likewise inadequate to Wexler's project, but for very different reasons. In contrast to Kaplan's elegance, Wexler's argument is, for lack of a better word, “messy”- pulled hither and yon by an interpretive exuberance that follows no single method, and sustains no single argument. Indeed, even as she draws with great sophistication on an impressive range of theoretical material, ultimately she approaches her material with a flamboyant pragmatism.

Rather, Kaplan and Wexler challenge us to think more critically than theoretically about the cultures they study, the cultures they (and we) inhabit, and how they (and we) go about bringing the two in contact as historians, as critics, and as citizens. In revising how we understand domesticity, Mark Twain, and Theodore Roosevelt, Kaplan simultaneously emphasizes the complicity of her subjects in the culture of empire, and our complicity in it. In this sense her book critically "intervenes" (to use a word freighted with the aura of cultural studies jargon) in the production of historical knowledge that came to maturity in the Gilded Age and continues today. 
Wexler's critique is more complex because she grounds it as much in how she engages with her material as she does in what that material says about the past. For to read for absence, to insist that was is invisible in a photograph is significant, is to set at critical odds the perception of the present with that of the past. It is to pronounce, perhaps against the experience of those who lived in the past, a value judgment about what they themselves found worth preserving, to look for what is not visible, can take place only as cultural critique. Wexler thus risks the most presumptuous sort of anachronism by holding people of the past responsible for a future they could not see. Who are we to make such a judgment on those who had no better vision of what might come than we do, but whose range of possible futures that filled their understanding of their present we have no hope of recovering? And yet, alongside this historical hubris, operates a profound respect. To hold people in the past responsible for the future is no less than what a critical cultural consciousness expects of those living in society today. Thus to critique the power of absence challenges those of us producing culture today to heed our own blindness and critically examine our own values. And finally, Wexler's work reminds all of us who labor in the field of culture, of how culture not only implicates us in historical dynamics we may not like, but as well enables us to see after the fact more than we know at the moment. We take pictures, we write accounts of our experiences, and narrate those of others precisely to register and even explain moments that we feel inadequate to understanding. In doing so, as the Cooks did in Virginia over a century ago, we trust representation not just to "capture" a moment, but to fill it with a significance we can only sense, a significance that reaches far beyond our present capacities for understanding. 
At its best, cultural critique insists on the necessity of this commitment both to the past's obligation to the present and its failures and blindness, and the present's obligation to the fullness of meaning of the past. This is not theory, though theory helps us see this. This is not history, though history establishes the rubrics for knowledge about the past. And it is not American studies, though the field has proven proficient in at least sustaining such critique. This is what we do as inhabitants of the worlds we help make. 